\title{
Emerging roles of L-type voltage-gated and other calcium channels in T Iymphocytes
}

\author{
Abdallah Badou ${ }^{1+}$, Mithilesh K. Jha ${ }^{2+}$, Didi Matza ${ }^{3}$ and Richard A. Flavell ${ }^{4,5} *$ \\ ' Equipe de recherche Environnement et Santé, Faculté Polydisciplinaire de Safi, Université Cadi Ayyad, Safi, Morocco \\ ${ }^{2}$ Trudeau Institute, Saranac Lake, NY, USA \\ ${ }^{3}$ Department of Cardiothoracic Surgery, Hadassah Medical Center, Jerusalem, Israel \\ ${ }^{4}$ Flavell Laboratory, Department of Immunobiology, Yale University School of Medicine, New Haven, CT, USA \\ ${ }^{5}$ Howard Hughes Medical Institute, New Haven, CT, USA
}

\section{Edited by:}

Gergely Toldi, Semme/weis

University, Hungary

Reviewed by:

Christian Schönbach, Kyushu Institute of Technology, Japan

Tomasz Zal, University of Texas MD Anderson Cancer Center, USA

\section{*Correspondence:}

Richard A. Flavell, Yale University School of Medicine, 300 Cedar

Street, TAC S-569, New Haven, CT 06520-8011, USA

e-mail: richard.flavell@yale.edu

${ }^{+}$Abdallah Badou and Mithilesh K. Jha have contributed equally to this work.
In T lymphocytes, calcium ion controls a variety of biological processes including development, survival, proliferation, and effector functions. These distinct and specific roles are regulated by different calcium signals, which are generated by various plasma membrane calcium channels. The repertoire of calcium-conducting proteins in T lymphocytes includes store-operated CRAC channels, transient receptor potential channels, P2X channels, and L-type voltage-gated calcium ( $\left.\mathrm{C}_{\mathrm{v}} 1\right)$ channels. In this paper, we will focus mainly on the role of the $\mathrm{Ca}_{\mathrm{v}} 1$ channels found expressed by $\mathrm{T}$ lymphocytes, where these channels appear to operate in a T cell receptor stimulation-dependent and voltage sensor independent manner. We will review their expression profile at various differentiation stages of CD4 and CD8 $T$ lymphocytes. Then, we will present crucial genetic evidence in favor of a role of these $\mathrm{Ca}_{v} 1$ channels and related regulatory proteins in both CD4 and CD8T cell functions such as proliferation, survival, cytokine production, and cytolysis. Finally, we will provide evidence and speculate on how these voltage-gated channels might function in the T lymphocyte, a non-excitable cell.

Keywords: $\mathrm{Ca}_{\mathrm{v}} 1$ channels, calcium channels, CD4T cells, CD8T cells, CRAC channel

\section{INTRODUCTION}

$\mathrm{T}$ cells require $\mathrm{Ca}^{2+}$ for their development and function (1-4). A canonical pathway for $\mathrm{Ca}^{2+}$ entry into $\mathrm{T}$ cells has been described thus far. Accordingly, ligation of T Cell Receptor (TCR) leads to activation of phosphoinositide-specific phospholipase C (PLC) $\gamma$. PLC $\gamma$ breaks down phosphatidylinositol-4,5-bisphosphate to generate inositol-1,4,5-trisphosphate $\left(\mathrm{IP}_{3}\right)$ and diacylglycerol (DAG). $\mathrm{IP}_{3}$ activates the release of $\mathrm{Ca}^{2+}$ into the cytoplasm by binding to $\mathrm{IP}_{3}$ receptors $\left(\mathrm{IP}_{3} \mathrm{R}\right)$ located on the surface of internal $\mathrm{Ca}^{2+}$ stores, such as the endoplasmic reticulum (ER). Store-operated calcium (SOC) channels in the plasma membrane are then activated by the store depletion (5-7). A requirement for sustained signaling arises largely from the need to recruit and retain Nuclear Factor of Activated T cells (NFAT), a key transcriptional regulator of the IL-2 gene and other cytokine genes, in the nucleus (8).

There are several families of plasma membrane channels expressed in T cells. The most studied channels in lymphocytes are known as "calcium release-activated calcium" (CRAC) channels (5, 9, 10). A breakthrough in their characterization occurred after the identification of stromal interaction molecule (STIM), which is an ER-resident $\mathrm{Ca}^{2+}$ sensor, and ORAI/CRACM (CRAC modulator), which is their pore-forming subunit (11-14). The transient receptor potential (TRP) channels have also been detected in T cells and reported to be functionally involved in $\mathrm{Ca}^{2+}$ entry possibly after store depletion (15-17). Finally, evidence for the expression of P2X receptor channels on the plasma membrane and for their contribution to $\mathrm{Ca}^{2+}$ entry in lymphocytes was also shown (18-20).

\section{EXPRESSION OF Ca $\mathrm{Ca}_{V}$ CHANNELS IN T CELLS}

$\mathrm{Ca}_{\mathrm{v}}$ channels are heteromultimers that are composed of a poreforming $\alpha 1$ subunit, $\beta$ regulatory subunit, and $\alpha 2, \gamma$, and $\delta$ subunits (21). The topology of the $\alpha 1$ pore subunit is predicted to have four repeated motifs (I-IV), each of which is hexahelical and contains a loop between the S5 and S6 transmembrane segments that forms the channel pore. The $S 4$ transmembrane segments in each motif contain conserved positively charged amino acids that are voltage sensors and that move outwards upon membrane depolarization, thereby opening the channel (22).

Several studies, including our own, have shown that $\mathrm{CD} 4^{+}$and $\mathrm{CD}^{+} \mathrm{T}$ cells express high levels of the $\mathrm{Ca}_{\mathrm{v}} 1$ pore-forming subunit subfamily $\left(\mathrm{Ca}_{\mathrm{v}} 1.1-1.4\right.$ or $\alpha 1 \mathrm{~S}, \alpha 1 \mathrm{C}, \alpha 1 \mathrm{D}$, and $\alpha 1 \mathrm{~F}$, respectively), but not $\mathrm{Ca}_{\mathrm{v}} 2(\alpha 1 \mathrm{~A}, \alpha 1 \mathrm{~B}, \alpha 1 \mathrm{E})$ or $\mathrm{Ca}_{\mathrm{v}} 3(\alpha 1 \mathrm{G}, \alpha 1 \mathrm{H}, \alpha 1 \mathrm{I})$ subfamilies (see Table 1); moreover they express these molecules at levels comparable with those in excitable cells (23-32).

We showed that the $\mathrm{Ca}_{\mathrm{v}} 1.1$ pore subunit is expressed in naïve $\mathrm{CD}^{+} \mathrm{T}$ cells and its expression is upregulated during primary stimulation of these cells $(27,29,35)$. In $\mathrm{CD}^{+} \mathrm{T}$ cells, this subunit is only expressed in effector cells, late after primary stimulation and during secondary stimulation $(31,33)$.

The $\mathrm{Ca}_{\mathrm{v}} 1.2$ pore subunit is apparently not detected in naïve $\mathrm{CD}^{+}$or $\mathrm{CD} 8^{+} \mathrm{T}$ cells. In the CD4 compartment, effector Th2 $\mathrm{CD}^{+}$cells selectively express this subunit and it is not expressed in effector $\mathrm{CD} 8^{+} \mathrm{T}$ cells. In $\mathrm{CD} 8^{+} \mathrm{T}$ cells, its protein expression seems to be upregulated briefly during primary stimulation (usually peaks at day 3 or 4 after in vitro stimulation of $\mathrm{CD} 8^{+} \mathrm{T}$ cells using anti-CD3 and anti-CD28 coated plates) (33). 
Table 1 | Role of distinct $\mathrm{Ca}^{2+}$-permeable channels in $\mathrm{T}$ lymphocyte development and functions.

\begin{tabular}{|c|c|c|c|c|c|}
\hline \multirow[t]{2}{*}{ Channel } & \multicolumn{3}{|c|}{ Role in T lymphocytes } & \multirow[t]{2}{*}{ Evidence } & \multirow[t]{2}{*}{ Reference } \\
\hline & Development & Naive & Differentiated & & \\
\hline $\begin{array}{l}\mathrm{Ca}_{v} 1.2 \\
\mathrm{Ca} 1.3\end{array}$ & ND & $\begin{array}{l}\text { No apparent } \\
\text { expression }\end{array}$ & $\begin{array}{l}\text { Involvement in TCR-mediated } \\
\text { calcium influx in Th2 cells and } \\
\text { in Th2 effector functions } \\
\text { in vitro and in vivo }\end{array}$ & $\begin{array}{l}\text { dihydropyridines } \\
\text { antagonists and } \\
\text { knockdown with } \\
\mathrm{Ca}_{\mathrm{v}} 1 \text { antisense } \\
\text { oligodeoxynu- } \\
\text { cleotides }\end{array}$ & $\begin{array}{l}{[(34) \# 6 ;(60)} \\
\# 195 ;(27) \# 3 ;(36) \\
\# 280]\end{array}$ \\
\hline ORAI1 & $\begin{array}{l}\text { No apparent } \\
\text { effect in } \\
\text { ORAl1-deficient } \\
\text { mice }\end{array}$ & $\begin{array}{l}\text { No apparent effect in } \\
\text { ORAl1-deficient } \\
\text { mice }\end{array}$ & $\begin{array}{l}\text { Involvement in TCR-mediated } \\
\mathrm{Ca}^{2+} \text { influx and effector } \\
\text { functions (in T cells from SCID } \\
\text { patients) and contribution to } \\
\text { TCR-mediated } \mathrm{Ca}^{2+} \text { influx and } \\
\text { effector functions (in } \\
\text { ORAl1-deficient T cells from } \\
\text { mice) }\end{array}$ & $\begin{array}{l}\text { T cell lines from } \\
\text { SCID patients and } \\
\text { primary murine T } \\
\text { cells from ORAl1 KO } \\
\text { mice }\end{array}$ & $\begin{array}{l}{[(13) \# 211 ;(14)} \\
\# 212 ;(74) \# 249]\end{array}$ \\
\hline TRPM2 & $\begin{array}{l}\text { No apparent } \\
\text { effect in } \\
\text { TRPM2-deficient } \\
\text { mice }\end{array}$ & $\begin{array}{l}\text { Reduced } \\
\text { TCR-mediated } \\
\text { proliferation }\end{array}$ & $\begin{array}{l}\text { Contribution to production of } \\
\text { pro-inflammatory cytokines } \\
\text { after stimulation via TCR }\end{array}$ & TRPM2 KO mice & [(89) \#266] \\
\hline TRPM7 & $\begin{array}{l}\text { defect in T cell } \\
\text { development in } \\
\text { the thymus }\end{array}$ & ND & ND & TRPM7 KO mice & [(91) \#268] \\
\hline $\begin{array}{l}\mathrm{P} 2 \mathrm{X} 7, \mathrm{P} 2 \mathrm{X} 1 \text {, and } \\
\mathrm{P} 2 \mathrm{X} 4 \text { receptor } \\
\text { channels }\end{array}$ & $\begin{array}{l}\text { No apparent } \\
\text { effect in P2X7 } \\
\text { deficient mice } \\
\text { and ND for P2X1 } \\
\text { and P2X4 }\end{array}$ & ND & $\begin{array}{l}\text { Critical for TCR-dependent, } \\
\text { ATP-mediated } \mathrm{Ca}^{2+} \text { influx and } \\
\text { downstream signaling events } \\
\text { accompanying } T \text { cell activation }\end{array}$ & $\begin{array}{l}\text { P2X7 receptor KO } \\
\text { mice and siRNA for } \\
\text { P2X7, P2X1, and } \\
\text { P2X4 receptor } \\
\text { channels. Jurkat } \\
\text { cells and human } \\
\text { peripheral CD4+T } \\
\text { cells were used }\end{array}$ & $\begin{array}{l}{[(18) \# 270 ;(19)} \\
\# 276 ;(20) \# 271]\end{array}$ \\
\hline
\end{tabular}

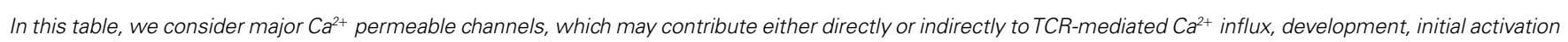

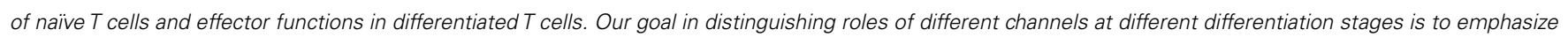
areas where more research efforts are needed in order to understand the contribution of these Ca ${ }^{2+}$ channels in $T$ lymphocyte development and functions. Cav, voltage-gated $\mathrm{Ca}^{2+}$ channel; TRP, transient receptor potential; P2XR, P2X receptors; TCR, T cell receptor; Th, T helper; ND, not determined. 
The $\mathrm{Ca}_{\mathrm{v}} 1.3$ pore subunit is expressed in effector Th2, but not in naïve, $\mathrm{CD}^{+}{ }^{+} \mathrm{T}$ cells (36). Its mRNA was detected in naïve and effector $\mathrm{CD}^{+} \mathrm{T}$ cells but no information is yet available regarding the protein expression profile in these cells. Finally, the $\mathrm{Ca}_{\mathrm{v}} 1.4$ pore subunit is expressed in naïve $\mathrm{CD}^{+}{ }^{+}$and $\mathrm{CD} 8^{+} \mathrm{T}$ cells $(31,32)$. Apparently $\mathrm{T}$ cells express all the rest of the $\mathrm{Ca}_{\mathrm{v}}$ complex subunits, including the regulatory $\beta$ subunits, $\gamma$ subunits, as well as $\alpha 2$, and $\delta$ subunits. It is therefore likely that these cells express a fully functional $\mathrm{Ca}_{\mathrm{v}}$ channel, possibly similar to the ones found in excitable cells $(25,27)$. Other studies have also shown that these channels are widely expressed in various other immune cell types, such as Dendritic cells (DC), B-lymphocytes, and monocytes (37-39).

In addition to the expression of a full $\mathrm{Ca}_{\mathrm{v}}$ complex, other similarities exist between excitable and non-excitable cells in relation to the $\mathrm{Ca}_{\mathrm{v}}$ pathway. In striated muscle, $\mathrm{Ca}_{\mathrm{v}}$ channels, expressed on the plasma membrane, are physically linked to Ryanodine receptors (RyR), expressed in the Sarcoplasmic Reticulum (SR). During a process called excitation-contraction coupling (E-C coupling), depolarization of the t-tubule membrane (i.e., excitation) induces extracellular $\mathrm{Ca}^{2+}$ flow through $\mathrm{Ca}_{\mathrm{v}}$ channels (which are gated by the function of their voltage sensor) that lead to activation of RyR channel in the SR membrane. The activation of RyR channels leads to massive $\mathrm{Ca}^{2+}$ release from the SR, which in turn initiates contraction (40). Therefore, unlike T cells, muscle cells first obtain $\mathrm{Ca}^{2+}$ from the extracellular space that initiates the entire process of $\mathrm{Ca}^{2+}$ release from intracellular stores.

It seems that $\mathrm{T}$ cells also express all the components necessary for such a mechanism described above, i.e., RyRs and $\mathrm{Ca}_{\mathrm{v}}$ channels. Primary T cells express RyR2, and they upregulate its expression after treatment with stromal cell-derived factor 1 (SDF$1)$, macrophage-inflammatory protein-1 $\alpha$ (MIP1 $\alpha)$, or TGF- $\beta$. Other hemopoietic cells also express RyRs $(41,42)$. RyRs, expressed in $\mathrm{T}$ cells, can be activated pharmacologically to mobilize $\mathrm{Ca}^{2+}$ from intracellular stores independently from $\mathrm{IP}_{3} \mathrm{R}$ (43). On the other hand, pharmacological blocking of RyRs in $\mathrm{T}$ cells results in reduced proliferation and IL-2 production (44). Knockdown of RyR3, the RyR that is expressed mainly by Jurkat T cells (primary $\mathrm{T}$ cells express RyR2 mostly), resulted in a significant reduction in $\mathrm{Ca}^{2+}$ entry in response to TCR cross-linking using anti-CD3 (45).

Finally, a recent study has suggested that, similar to excitable cells, store-operated $\mathrm{Ca}^{2+}$ entry via TCR stimulation precedes $\mathrm{Ca}^{2+}$ release from intracellular stores via $\mathrm{IP}_{3} \mathrm{R}$ and RyRs (46). Further studies are required to determine if $\mathrm{Ca}_{\mathrm{v}}$ channels are associated with RyRs in $\mathrm{T}$ cells and what are their roles in $\mathrm{T}$ cell activation.

\section{ROLE OF $\beta$ REGULATORY SUBUNITS AND $\mathrm{Ca}_{\mathrm{v}} 1$ CHANNELS IN T CELL ACTIVATION AND FUNCTION}

Numerous lines of evidence demonstrating the expression of $\mathrm{Ca}_{\mathrm{V}}$ channels have indicated roles of these channels in $\mathrm{T}$ cell biology (see Table 1). A potential role for $\mathrm{Ca}_{\mathrm{v}}$ channels in $\mathrm{T}$ cells became evident in mice with lethargic mutation, which arose spontaneously in the inbred mouse strain BALB/cGn in 1962. Homozygotes are recognizable at 2 weeks of age by ataxia, seizures, and lethargic behavior (47, 48). In 1997, Burgess et al. demonstrated that the ataxia and seizures in the lethargic mouse arise from a mutation of the $\beta 4$ subunit gene (49). Neither full-length nor truncated $\beta 4$ protein is expressed in the mutant mice (49). Interestingly, these mice experience an immunological disorder, including a defect in their cell-mediated immune response (50). $\beta$ regulatory subunits, $\beta 1-\beta 4$, are crucial for normal $\mathrm{Ca}_{\mathrm{v}}$ channel function (51), since they are required for the expression of functional channels at the plasma membrane (52), and modulate their biophysical properties by interacting with pore-forming $\alpha$ subunit (51). The mechanism of immune disorder described in these lethargic $\beta 4$ mutant mice was unknown but of great interest since it implicitly supported the hypothesis that components of $\mathrm{Ca}_{\mathrm{v}} 1$ channels are expressed in immune cells and play a crucial role in the activation and function of immune cells.

We and others demonstrated that human and mouse $\mathrm{T}$ cells express regulatory $\beta 3$ and $\beta 4$ subunits $(23-25,27,31,33,53)$. In 2006 , we provided genetic evidence, for the first time, that CD4 ${ }^{+}$ T cells deficient in either $\beta 3$ and $\beta 4$ are impaired in $\mathrm{Ca}^{2+}$ response, NFAT activation, and cytokine production (27). Interestingly, in the $\beta 4$-deficient $\mathrm{T}$ cells, we have also detected a notable and specific suppression of the $\mathrm{Ca}_{\mathrm{v}} 1.1$ pore-forming $\alpha 1$ subunit protein. On the other hand, no significant effect was observed in the expression of the $\mathrm{Ca}_{\mathrm{v}} 1.2$ channel protein. This observation suggests that the deficiency observed in the $\beta 4$-deficient mice might be due to the lack of expression of the $\mathrm{Ca}_{\mathrm{v}} 1.1$ channel (27). However, the exact mechanism of the requirement of multiple $\beta$ regulatory subunits in effector T cell stage is still unknown.

In $\mathrm{CD} 8^{+} \mathrm{T}$ cells, we found that $\beta 3$ is highly expressed in naïve and activated $\mathrm{CD} 8^{+} \mathrm{T}$ cells and $\beta 3$ deficiency leads to enhanced apoptosis of naïve $\mathrm{T}$ cells and decrease in homeostatic survival of these cells (31). We found that the impaired $\mathrm{Ca}^{2+}$ influx in $\beta 3$-deficient $\mathrm{CD}^{+} \mathrm{T}$ cells was associated with a lack of $\mathrm{Ca}_{\mathrm{v}} 1.4$ protein expression (31). The functional defect in both $\beta 4$ - and $\beta 3$ deficient $\mathrm{T}$ cells reflected the contribution of these subunits to $\mathrm{Ca}_{\mathrm{v}} 1$ channel-dependent calcium response in T lymphocytes $(27,31)$.

Consistent with our findings (31), Omilusik et al. analyzed $\mathrm{Ca}_{\mathrm{v}}$ 1.4-deficient mice and reported that $\mathrm{CD}^{+}{ }^{+}$and $\mathrm{CD} 8^{+} \mathrm{T}$ cells from $\mathrm{Ca}_{\mathrm{v}} 1.4$-deficient mice had impaired homeostatic maintenance (32). $\beta 3$ or $\mathrm{Ca}_{\mathrm{v}}$ 1.4-deficient $\mathrm{T}$ cells also had increased rates of cell death $(31,32)$. Naive $\mathrm{CD}^{+}$and $\mathrm{CD}^{+} \mathrm{T}$ cells were shown to be dependent on $\mathrm{Ca}_{\mathrm{v}} 1.4$ function for SOCE, TCR-induced rises in cytosolic $\mathrm{Ca}^{2+}$ and downstream TCR signal transduction. The generation of antigen-specific $\mathrm{T}$ cell responses was altered in the absence of $\beta 3$ or $\mathrm{Ca}_{\mathrm{v}} 1.4(31,32)$ since these mice failed to mount an effective $\mathrm{T}$ cell response to antigen challenge, and this was associated with reduced effector function of $\mathrm{CD}^{+} \mathrm{T}$ cells (32).

Unexpectedly, we found that $\beta 3$ and $\mathrm{Ca}_{\mathrm{v}} 1.4$ were associated with a $\mathrm{T}$ cell signaling complex in primary $\mathrm{T}$ cells that was not dependent on TCR stimulation, which suggested that a preformed complex of these proteins exists in naive T cells (31). Furthermore, we identified a fraction of $\mathrm{Ca}_{\mathrm{v}} 1.4$ as a lipid raft-resident $\mathrm{Ca}^{2+}$ channel protein (31). The reported interaction of $\mathrm{Ca}_{\mathrm{v}} 1.4$ with filamins in spleen cells (54) combined with our finding of its association with Lck and Vav highlight a $\mathrm{Ca}_{\mathrm{v}}$ channeldependent molecular architecture of a signaling complex in specialized microdomains of T cells. These observations further gain importance given the widely accepted model that the specificity, reliability, and accurate execution of signaling processes depend on 
tightly regulated spatiotemporal $\mathrm{Ca}^{2+}$ signals restricted to precise microdomains that contain $\mathrm{Ca}^{2+}$-permeable channels and their modulators $(55,56)$.

Similar to $\beta 3$ deficiency, analyses of thymocytes lacking a functional $\mathrm{Ca}_{\mathrm{v}} 1.4$ channel revealed unperturbed or subtle changes in $\mathrm{T}$ cell compartment $(31,32)$. In thymus, the expression of various maturation and activation markers such as TCR $\beta, \operatorname{CD} 44$, CD69, and CD62L were similar on $\mathrm{Ca}_{\mathrm{v}} 1.4^{-/-}$and WT double positive (DP) and TCR $\beta^{+}$SP subpopulations (32). $\mathrm{Ca}_{\mathrm{v}} 1.4$-deficient SP thymocytes exhibited very moderate decreases in TCR- or thapsigargin-induced rises in cytosolic-free $\mathrm{Ca}^{2+}$ relative to WT. In contrast to thymocytes, $\mathrm{Ca}_{\mathrm{v}} 1.4^{-/-}$peripheral naive, and memory $\mathrm{T}$ cells were significantly impaired in TCR- or thapsigargin-induced rises in cytosolic-free $\mathrm{Ca}^{2+}$ compared to WT peripheral naive and memory $\mathrm{T}$ cells (32). This indicates the great complexity involved in $\mathrm{Ca}^{2+}$ regulation, dynamically changing with $\mathrm{T}$ cell differentiation, and suggests that differential responses are important for functional outcomes upon TCR engagement. These two independent studies indicated that $\mathrm{Ca}_{\mathrm{v}} 1.4 / \beta 3$ complex-mediated influx of $\mathrm{Ca}^{2+}$ from outside the cell probably induces a signaling cascade as well as contributes to tonic filling of intracellular $\mathrm{Ca}^{2+}$ stores critical for TCR survival signaling $(31,32)$.

\section{DIFFERENTIIAL REGULATION OF T CELL SURVIVAL BY $\mathrm{Ca}_{\mathrm{v}}$ VS. CRAC CHANNELS}

While $\beta 3^{-/-}$or $\mathrm{Ca}_{\mathrm{v}} 1.4^{-/-}$naïve T cells die spontaneously $(31,32)$, it was surprising to find an enhanced T cell survival and proliferation in the absence of ORAI1/CRACM1 (57). CD4 ${ }^{+} \mathrm{T}$ cells from $\mathrm{Orail}^{-/-}$mice showed robust proliferation with repetitive stimulations and strong resistance to stimulation-induced cell death due to reduced mitochondrial $\mathrm{Ca}^{2+}$ uptake and altered gene expression of proapoptotic and antiapoptotic molecules. Orai1 ${ }^{-/-}$mice showed strong resistance to $\mathrm{T}$ cell depletion induced by injection of anti-CD3 Ab. Furthermore, ORAI1-deficient T cells showed enhanced survival after adoptive transfer into immunocompromised hosts. Together, therefore these data suggest a unique requirement of $\mathrm{Ca}_{\mathrm{v}} 1$ calcium channels, not ORAI1/CRACM1 channel, in the survival, homeostasis, and proliferation of naïve $\mathrm{T}$ cells. While ORAI1/CRACM1 channels are undoubtedly required for the effector/late T cell functions (see Figure 1), others and our data also argue for a requirement for $\mathrm{Ca}_{\mathrm{v}} 1$ calcium channels in the effector stage of T cells (27,31-33). Although, it is clear now that both types of calcium channels ( $\mathrm{Ca}_{\mathrm{v}} 1$ and ORAI1/CRACM1) play critical roles in $\mathrm{T}$ cell biology, the present state of knowledge does not rule out a cross talk between $\mathrm{Ca}_{\mathrm{v}} 1$ and ORAI1/CRACM1 calcium channels at the effector stage of $\mathrm{T}$ cells where all different kinds of calcium channels $\left(\mathrm{Ca}_{\mathrm{v}} 1.1, \mathrm{Ca}_{\mathrm{v}} 1.2, \mathrm{Ca}_{\mathrm{v}} 1.3, \mathrm{Ca}_{\mathrm{v}} 1.4\right.$, and ORAI1/CRACM1) are co-expressed and deficiencies in these channels show immune defects. Indeed, STIM1 was shown to reciprocally control $\mathrm{Ca}_{\mathrm{v}} 1.2$ and ORAI1 channels. While STIM1 activates the ORAI1 channel, it blocks $\mathrm{Ca}_{\mathrm{V}} 1.2$ channel activity (58, 59). When $\mathrm{Ca}_{\mathrm{v}} 1.2$ was introduced into Jurkat T cell lines expressing reduced levels of STIM1, the authors were able to measure a significant depolarization-induced increase in $\left[\mathrm{Ca}^{2+}\right] \mathrm{i}$ compared to WT Jurkat cells (59). This suggests that loss of STIM1 allowed $\mathrm{Ca}_{\mathrm{v}} 1.2$ activation in these cells. This was further confirmed by using shRNA to suppress STIM1. The regulation of
$\mathrm{Ca}_{\mathrm{v}} 1.2$ by STIM1 occurs through direct interaction since by using co-immunoprecipitation, it was shown that these two proteins cointeract after overexpression but also at their physiological expression level in neuroblastoma cells. Furthermore, it was reported that STIM1 binds to the $\mathrm{C}$ terminal region of $\mathrm{Ca}_{\mathrm{v}} 1.2$ through its CRAC activation domain (CAD) $(58,59)$. These observations may explain how these two widely expressed channel families, $\mathrm{Ca}_{\mathrm{v}} 1$ and ORA1, could function in the same cell type to trigger different signaling pathways, potentially leading to the control of different functions (Figure 1).

\section{ROLE OF Ca $\mathrm{a}_{\mathrm{v}}$ CHANNELS IN T CELL DIFFERENTIATION AND INFLAMMATORY DISORDERS}

Savignac et al. demonstrated that expression of $\mathrm{Ca}_{\mathrm{v}} 1$ channels was induced during Th2 cell differentiation (60). Agonists and antagonists for $\mathrm{Ca}_{\mathrm{v}} 1$ channels modulate the TCR-dependent increase in $\left[\mathrm{Ca}^{2+}\right]_{\mathrm{i}}$ and IL-4 production by Th2 cells, whereas they failed to alter the Th1 cell responses. The administration of nicardipine, a specific and clinically approved inhibitor for $\mathrm{Ca}_{\mathrm{v}} 1$ channels, was found beneficial in three models of Th2-mediated immunopathology but did not prevent experimental autoimmune encephalomyelitis (EAE), an experimental model of Th1-mediated autoimmune disease $(60,61)$. These studies highlighted that TCRdependent calcium signaling differs between Th2 and Th1 cells and suggested an important role of $\mathrm{Ca}_{\mathrm{v}} 1$ channels in the selective regulation of $\left[\mathrm{Ca}^{2+}\right]_{\mathrm{i}}$ on stimulation through the TCR in Th2 cells. It is important to note that drugs targeting $\mathrm{Ca}_{\mathrm{v}} 1$ channels may be beneficial in the treatment of pathologies associated with Th2 cell-mediated immunopathology.

Further, it is reported that differentiation in Th2 cells but not in Th1 cells was associated with the up-regulation of $\mathrm{Ca}_{\mathrm{v}} 1.2$ and $\mathrm{Ca}_{\mathrm{v}} 1.3$ channels both at the mRNA and protein level (36). Depletion of $\mathrm{Ca}_{\mathrm{v}} 1.2$ and $\mathrm{Ca}_{\mathrm{v}} 1.3$ expression by antisense oligodeoxynucleotides in $\mathrm{T}$ cells reduced TCR-induced $\mathrm{Ca}^{2+}$ influx in Th2 cells, attenuated IL-4 production and reduced airway inflammation in a mouse model of allergic asthma (36). Moreover, ovalbumin (OVA)-specific transgenic Th2 cells transfected with $\mathrm{Ca}_{\mathrm{V}} 1$-specific antisense $\left(\mathrm{Ca}_{\mathrm{V}} 1 \mathrm{AS}\right)$ oligodeoxynucleotides were no longer able to induce asthma on adoptive transfer in BALB/c mice given intranasal OVA. The intranasal administration of $\mathrm{Ca}_{\mathrm{V}} 1 \mathrm{AS}$ at the time of intranasal challenge with OVA was effective in active experimental asthma, preventing airway inflammation, Th2 cell activation in the lung draining lymph nodes, and airway hyperreactivity (36).

\section{MECHANISM OF $\mathrm{Ca}_{\mathrm{v}} 1$ CHANNEL MEDIATED REGULATION OF CA $^{2+}$ SIGNALING IN T LYMPHOCYTES}

Others and we demonstrated the presence and significance of $\mathrm{Ca}_{\mathrm{v}} 1$ channels in $\mathrm{T}$ cells (see Table 1$)(23,25,27,31,33,53)$. However, it is not known how these $\mathrm{Ca}_{\mathrm{v}} 1$ channels open in $\mathrm{T}$ cells to conduct calcium. In excitable cell types, $\mathrm{Ca}_{\mathrm{v}}$ channels conduct $\mathrm{Ca}^{2+}$ upon depolarization $(62,21)$. The basic question here is whether $\mathrm{Ca}_{\mathrm{v}} 1$ channels are activated by TCR stimulation or by depolarization. From a physiological standpoint, $\mathrm{T}$ cells should respond only to antigen stimulation through cognate TCR. A voltage-dependent opening in the absence of TCR dependence would lead to a random opening of $\mathrm{Ca}_{\mathrm{v}}$ channels 


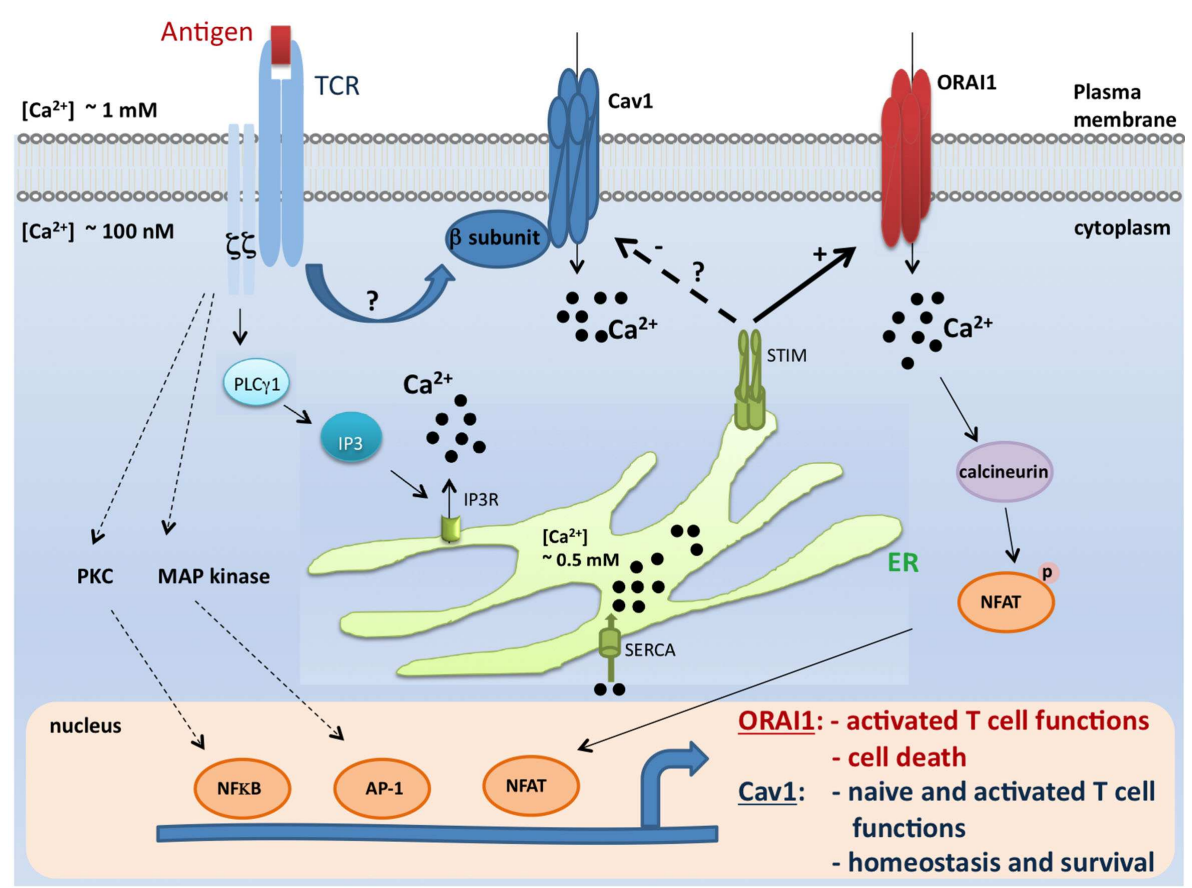

FIGURE 1 | A model for coordinated control of $\mathrm{Ca}_{\mathrm{v}} \mathbf{1}$ and ORAl1 channels in T lymphocytes. Antigen encounter by T cells results in the activation of numerous pathways including the $\mathrm{Ca}^{2+}$ pathway. Mechanisms of $\mathrm{Ca}^{2+}$ influx through two major $\mathrm{Ca}^{2+}$-permeable channels, $\mathrm{Ca}_{\mathrm{v}} 1$ and ORAl1, are depicted in this scheme. During the course of biological functions that require activation of the STIM/ORAI pathway (such as effector functions and apoptosis), STIM1 blocks $\mathrm{Ca}_{\mathrm{v}} 1$ channel activity and all depending $\mathrm{T}$ cell functions. In contrast, this inhibitory effect would be lifted when $\mathrm{Ca}_{\mathrm{v}}$ 1-dependent $\mathrm{T}$ cell functions (such as survival and naïve T cell activation) take place $(27,29,31-33,36$,
$57-59,77,78)$. It is, however, important to point out that the crosstalk described in this model was shown solely for $\mathrm{Ca}_{\mathrm{v}} 1.2$ channel, and no information is available to date for the relationship between STIM and other $\mathrm{Ca}_{v} 1$ channels. TCR, T cell receptor; $\mathrm{Ca}_{\mathrm{v}}$, voltage-gated $\mathrm{Ca}^{2+}$ channels; $\mathrm{ER}$, endoplasmic reticulum; IP3, inositol-1,4,5-trisphosphate; SERCA, sarco-endoplasmic reticulum $\mathrm{Ca}^{2+}$-ATPase; STIM1, stromal interaction molecule 1; PLC $\gamma 1$, phospholipase C $\gamma 1$; MAP kinase, Mitogen-activated protein kinase; PKC, protein kinase $\mathrm{C}$; NFkB, nuclear factor kB; AP-1, activator protein-1; and NFAT, nuclear factor of activated T cells. and subsequent activation of T cells, which could lead to immune activation in the absence of antigen. Unlike excitable cells, $\mathrm{T}$ cells migrate and roam the body through variable extracellular environments and tissues with various ion concentrations. It is therefore conceivable that $\mathrm{Ca}_{\mathrm{v}}$ channels expressed by $\mathrm{T}$ cells have developed a more specific control of their opening than mere voltage sensing. Notably, $\mathrm{Ca}_{\mathrm{v}} 1.4$, as well as $\mathrm{Ca}_{\mathrm{v}} 1.3$, has been found to have low activation thresholds that do not require strong depolarization for their activation (63). Earlier surprising findings showed that $\mathrm{Ca}_{\mathrm{v}} 1.3$ channels can be activated at voltages of approximately $-60 \mathrm{mV}$ under physiological calcium concentrations (64).

Since $\mathrm{Ca}_{\mathrm{v}} 1$ channels are expressed in T lymphocytes before and after TCR stimulation $(23,25,27,31,33,53)$, we tested the susceptibility of $\mathrm{T}$ cell $\mathrm{Ca}_{\mathrm{v}}$ channels to depolarization induced by $\mathrm{KCl}$. Artificial depolarization of $\mathrm{CD}^{+}{ }^{+} \mathrm{T}$ cells, which have been differentiated under Th1 (IL-12 plus anti-IL-4), Th2 (IL-4 plus anti-IFN $\gamma$ ), or Th0 (no cytokine) conditions, with $\mathrm{KCl}$ did not lead to calcium influx (27). $\mathrm{KCl}$ was used at $40 \mathrm{mM}$, a dose that induces a significant depolarization of T cells (27). However, under the same conditions and as expected, $\mathrm{KCl}$ triggered a transient calcium response in the $\mathrm{C} 2 \mathrm{C} 12$ skeletal muscle excitable cell line as previously reported (65). In addition, all four groups of cells, Th0, Th1, Th2, and $\mathrm{C} 2 \mathrm{C} 12$, were able to mount a calcium response after stimulation with the calcium ionophore, ionomycin (27). In agreement with our findings, other studies also have shown that treatment of T cells with $\mathrm{KCl}$ does not lead to calcium entry (25, 66) and in fact $\mathrm{KCl}$ addition seems to inhibit proliferation and IL2 production (67). These observations demonstrate that, unlike in excitable cells, depolarization of $\mathrm{T}$ cells does not induce $\mathrm{Ca}_{\mathrm{v}}$ channel opening.

\section{OTHER $\mathrm{CA}^{2+}{ }^{2}$-PERMEABLE CHANNELS EXPRESSED BY T LYMPHOCYTES}

The encounter of peptide-antigen presenting cell (APC) by naïve T cells induces a quick increase of intracellular calcium concentration in Tlymphocytes (4). This calcium increase could be sustained for hours at levels higher than basal standards in order to mediate appropriate $\mathrm{T}$ lymphocyte functions such as activation, proliferation, expression of various activation-associated genes such as cytokines and chemokines $(4,7,68)$. During their maturation stages, naïve T lymphocyte differentiate into distinct $\mathrm{T}$ cell subpopulations (such as Th1, Th2, Th17, and Treg), all of which require calcium signal. In light of these multitude and specific functions governed by $\mathrm{T}$ cells, it is logical to discover the expression, by these cell types, of various plasma membrane calcium channels, or even different levels of expression of the same channel at different stages of differentiation. In this section, we review the role of three major 
families of $\mathrm{Ca}^{2+}$ permeable channels expressed by $\mathrm{T}$ lymphocytes, SOC channels, TRP channels, and P2X receptor channels.

\section{STORE-OPERATED CALCIUM CHANNELS}

One well studied mechanism of calcium entry into $\mathrm{T}$ cells is the store-operated $\mathrm{Ca}^{2+}$ (SOC) entry process. This mechanism was suggested by Putney (69). In this study, the authors presented evidence showing that the $\mathrm{Ca}^{2+}$ released from ER stores could "directly" induce $\mathrm{Ca}^{2+}$ influx through plasma membrane calcium channels in cells that are non-excitable (69). Numerous and independent electrophysiological studies showed that $\mathrm{T}$ cells indeed express channels that can be opened in response to store depletion by distinct stimuli $(4,5,70)$. These channels have been designated CRAC channels in T cells, and have been extensively characterized at the electrophysiological level $(4,71)$ and are distinguished by a high selectivity for $\mathrm{Ca}^{2+}$ and a low conductance $(4,71)$. However, the molecular identity of the channels and their related regulatory proteins had remained unknown. In the year 2005, it has first been proposed, using RNA interference (RNAi)-based screen, that STIM 1, a conserved protein, is required for SOC influx both in Drosophila S2 cells and in Jurkat T cells (72). In a second study, by generating a point mutation in the STIM1 $\mathrm{Ca}^{2+}$ binding domain, it has been proposed that STIM1 operates as a $\mathrm{Ca}^{2+}$ store sensor, which functions by connecting $\mathrm{Ca}^{2+}$ store depletion to $\mathrm{Ca}^{2+}$ influx (11). In 2006, by using genome-wide approaches designed to identify regulators of store-operated $\mathrm{Ca}^{2+}$ entry, three separate groups have proposed a protein containing four transmembrane segments, ORAI1 (also named CRACM1) as the putative CRAC channel, or an essential component or related regulatory protein of the CRAC channel $(13,73,74)$. It was still not clear, at this stage, whether ORAI1 forms the CRAC channel itself. Using sitedirected mutagenesis, three additional studies have shown that it is indeed ORAI1 itself that forms the $\mathrm{Ca}^{2+}$ selectivity filter of the CRAC channel complex, providing strong evidence that ORAI1 is the pore-forming subunit of the CRAC channel $(14,75,76)$. In addition, the protein ORAI1 was proposed as the prototypical CRAC channel, especially after the discovery that human patients presenting with a SCID disease lack functional CRAC channels and SOCE in T cells (13). However, ORAI1 deficiency in mice resulted surprisingly in no defect in $\mathrm{T}$ cell development in the thymus, no defect in $\mathrm{T}$ cell proliferation and only a partial inhibition of IL-2 and IFN $\gamma$ production (77). In contrast, these mice exhibited a major defect in mast cell effector functions (77). It was also reported, in a second independent study, that $\mathrm{T}$ cell development is normal in ORAI1 ${ }^{-} /^{-}$mice and that ORAI1-deficient naive $\mathrm{CD} 4+\mathrm{T}$ cells and CD8 $+\mathrm{T}$ cells show no significant decrease of SOC influx after stimulation by thapsigargin or by anti-CD3 $\mathrm{mAb}$ (78). Consistently, ORAI1-deficient naive T cells exhibited normal proliferation upon stimulation with anti-CD3 and anti-CD28 mAbs (78). However, ORAI1 seemed to be of more importance to differentiated CD4+ and CD8+ T cells. Indeed, the impairment in $\mathrm{Ca}^{2+}$ influx in the absence of ORAI1 was most apparent in Th1 cells, followed by CTLs and then Th2 cells (78). Furthermore, when cytokine production was assessed, only a partial inhibition was observed in differentiated CD4+ and CD8 $+\mathrm{T}$ cells from ORAI1 ${ }^{-1-}$ mice (78). Interestingly, when cyclosporine A was applied, cytokine production was completely abolished (78), indicating that other calcium/calcineurin-dependent, ORAI1independent pathways are involved in this cytokine production in differentiated CD4 and CD8 T cells. The lack of a major contribution of ORAI1 is likely not due to a compensatory process by ORAI2 or ORAI3. In fact, while reconstitution with ORAI1 restored SOC influx in differentiated ORAI1-deficient T cells, reconstitution with ORAI2 protein showed no effect, and reconstitution with ORAI3 exhibited only a small SOC influx upon stimulation with thapsigargin but not anti-CD3 $\mathrm{mAb}$ (78). These observations suggest that ORAI1 is dispensable for T cell development and for initial intracellular calcium increases detected in naïve $\mathrm{T}$ cells upon the initial antigen encounter (see Table 1; Figure 1). However, ORAI1 is likely to contribute at least partially to CD4 and CD8 effector functions (see Table 1). This discovery is perhaps not completely surprising as the discovery phase of research on CRAC channels derived from studies in cell lines such as Jurkat, which are more similar, to some extent, to differentiated effector $\mathrm{T}$ cells rather than naive primary $\mathrm{T}$ cells. This observation also suggests that $\mathrm{Ca}^{2+}$ channels other than CRAC proteins are likely involved in $\mathrm{T}$ cell functions.

\section{TRANSIENT RECEPTOR POTENTIAL CHANNELS}

Before the discovery of ORAIl as the main channel responsible for SOC influx in T cells, members of the TRP family were considered as key candidates for $\mathrm{T}$ cell calcium channels. In human cells, TRP superfamily of channels can be classified into 7 subfamilies (TRPC, TRPV, TRPM, TRPA, TRPN, TRPP, and TRPML) with a total of 27 cation channels (79). These channels, which share six transmembrane domains, form ion-conducting proteins that are mostly non-selective and permeable to several cations, including $\mathrm{Ca}^{2+}$ and $\mathrm{Na}^{+}(80)$. TRP channels can be activated via diverse mechanisms. In fact, some TRP channels could respond to stimuli ranging from heat to natural product compounds, proinflammatory agents, and exocytosis (79). TRPC, TRPM, and TRPV seem to be the major subfamilies expressed by murine (81) and human T cells (82) (see Table 1). In 2003, Hoth and colleagues, by analyzing mutant $\mathrm{T}$ cell lines exhibiting defects in $\mathrm{Ca}^{2+}$ entry and $\mathrm{Ca}^{2+}$-dependent gene expression (83), suggested an alteration of TRPC3 gene in these mutant cell lines relative to wild type cells. When the wild type TRPC3 gene was reintroduced in mutant cell lines through transient transfection, it was able to restore TCRmediated $\mathrm{Ca}^{2+}$ influx. It was then concluded that TRPC3 channel contributes to TCR-induced $\mathrm{Ca}^{2+}$ entry into T cells, and is therefore critical for $\mathrm{Ca}^{2+}$-dependent activation of $\mathrm{T}$ cells (16). In this study, the authors used cell lines and overexpression approaches, and therefore, the conclusions needed to be confirmed in a more physiological system. A few years later, using murine immune cells the expression profile of diverse subsets of TRPC, TRPV, and TRPM was reported (81). Similarly, consistent mRNA expression of TRPC1, TRPC3, TRPV1, TRPM2, and TRPM7 was detected in primary human $\mathrm{CD} 4+\mathrm{T}$ cells purified from healthy donors. TRPC 3 and TRPM2 transcripts were upregulated after stimulation via TCR; and knockdown of TRPC 3 channel by siRNA showed that this channel may contribute to $\mathrm{Ca}^{2+}$-dependent proliferation of primary T cells (82). Another study pointed out a significant role of TRPC5 channel in the mechanism of effector T cell suppression by Treg cells (84). Interaction of these two cell types was described 
as involving cross-linking of GM1 ganglioside (expressed by effector T cells) by galectin-1 (expressed by Treg cells); and the TRPC5 channel was shown to be involved in this regulatory process. In this paper, the authors described the up-regulation of TRPC5 channel transcript, but not TRPC4, in effector murine CD4, and CD8 T cells relative to naïve T cells (84). They also showed that knockdown of TRPC 5 channel in effector T cells by short hairpin RNA inhibited both contact-dependent inhibition of effector $\mathrm{T}$ cell proliferation and galectin-1-induced $\mathrm{Ca}^{2+}$ influx (84). TRPM2 forms non-selective $\mathrm{Ca}^{2+}$-permeable cation channel. This channel is expressed in the brain but also in immune cells (85-87) and it can be opened by the intracellular messenger, adenosine $5^{\prime}$-diphosphoribose (ADPR) (85-87). One of the first reports on the role of TRPM2 (formerly LTRPC2) channel in calcium influx in immune cells demonstrated that the TRPM2 channel mediates $\mathrm{Ca}^{2+}$ influx into monocytes (86). This report showed that ADPR and nicotinamide adenine dinucleotide (NAD) can directly stimulate TRPM2 channel activity to mediate $\mathrm{Ca}^{2+}$ entry (86). A key question is whether these second messengers, NAD and/or ADPR, are involved in this process upon receptor stimulation. Guse and colleagues showed that indeed intracellular ADPR concentrations are increased upon stimulation of Jurkat $\mathrm{T}$ cells by ConA; and that this messenger mediates $\mathrm{Ca}^{2+}$ influx through TRPM2 channels (87). In this study, the authors also showed that inhibition of ADPR formation or knockdown of TRPM2 both inhibited this stimulation-dependent TRPM2-mediated $\mathrm{Ca}^{2+}$ influx (87). By modifying intracellular NAD concentration and using siRNA knockdown, another recent study similarly emphasized the role of NAD and ADPR in mitogen-induced $\mathrm{Ca}^{2+}$ rise in human T lymphocytes through the involvement of TRPM2 channels (88). Subsequently, using TRPM2-deficient mice, it was shown that this channel contributes to $\mathrm{T}$ lymphocyte proliferation and production of pro-inflammatory cytokines after stimulation via TCR (89). When evaluated in vivo, TRPM2 ${ }^{-1-}$ mice displayed amelioration in EAE development. The authors attributed this improved EAE phenotype to reduced $T$ cell effector functions and proposed TRPM2 channel as a potential therapeutic target (89).

Initial evidence for a role of the TRPM7 channel in immune cells emanated from its disruption in DT-40 B cell lines (90). TRPM7 deficient cells exhibited a defect in proliferation and required elevated extracellular $\mathrm{Mg}^{2+}$ for their survival (90). In a related interesting study, Clapham and colleagues used lck-Cre mice, since TRPM7 ${ }^{-1-}$ mice died prenatally, to selectively delete TRPM7 in T cells. Surprisingly, TRPM7flox ${ }^{-/-}$Lck-Cre mice displayed a notable defect in $\mathrm{T}$ cell development in the thymus. The authors detected a block in transition from the double negative $(\mathrm{CD} 4-\mathrm{CD} 8-)$ to DP $(\mathrm{CD} 4+\mathrm{CD} 8+)$ stage in TRPM7 deficient thymocytes. As a result, both the number and the percentage of $\mathrm{T}$ cells in the periphery are reduced. Interestingly, TRPM7 deficient thymocytes did not show any significant defect in $\mathrm{Mg}^{2+}$ uptake. And using inductively coupled plasma mass spectrometry, the authors showed that total $\mathrm{Mg}^{2+}$ concentration in wild type and deficient T cells is similar suggesting that TRPM7 is dispensable for cellular $\mathrm{Mg}^{2+}$ homeostasis in T cells (91). TRPM7 is a channel protein permeable to $\mathrm{Ca}^{2+}$ and $\mathrm{Mg}^{2+}$ but also contains a regulatory serine-threonine kinase domain in the same structure (92). A role for the kinase domain is likely to be also excluded. In fact, a recent study showed that the defect of TRPM7 deficient T cells in Fas-mediated apoptosis depends on its activity as a channel rather than a kinase (92). Therefore, after the involvement of $\mathrm{Mg}^{2+}$ and the kinase domain in this process have been excluded, the question arises as to whether the effects of the TRPM7 channel on $\mathrm{T}$ cell development are related to $\mathrm{Ca}^{2+}$.

In addition to TRPC and TRPM channels, other TRP channels such as TRPV1 and TRPV2 appear to show an interesting and consistent expression profile in primary human T cells (82), however, their role in $\mathrm{T}$ cell function is still elusive.

\section{P2X RECEPTOR CHANNELS}

$\mathrm{P} 2$ receptors are broadly distributed in many cell types. Two distinct subfamilies have been described, the G-protein-coupled seven-transmembrane $\mathrm{P} 2 \mathrm{Y}$ receptors and the ligand-gated $\mathrm{P} 2 \mathrm{X}$ receptors (P2XR) (18). There are seven mammalian $\mathrm{P} 2 \mathrm{X}$ receptor members ( $\mathrm{P} 2 \mathrm{X} 1-7)$. These proteins form non-selective cation channels that are gated by extracellular ATP to allow influx of cations including $\mathrm{Ca}^{2+}$, and $\mathrm{Na}^{2+}$. In $\mathrm{T}$ lymphocytes, three distinct P2X members have been suggested to contribute to calcium entry in human T cells, P2X1, P2X4, and P2X7 (20) (see Table 1). One of the first reports to suggest a potential expression of ATPgated receptor channels on T cells was published in 1996. In this article, it was shown that extracellular ATP (ATPe) was able to induce intracellular $\mathrm{Ca}^{2+}$ concentration increases in PBLs and purified human T cells (93). ATPe exhibited also a synergistic effect with $\mathrm{PHA}$ and anti-CD3 $\mathrm{mAb}$ on $\mathrm{PBL}$ proliferation. It was suggested, in this study, that the ATP-mediated $\mathrm{Ca}^{2+}$ influx and the ATP contribution in proliferation were both dependent on $\mathrm{P} 2 \mathrm{X}$ and/or $\mathrm{P} 2 \mathrm{Z}$ receptors since these effects were blocked using oxidized ATP (oATP), a covalent blocker of these two channels (93). In other reports, it was shown that ATPe was able to induce thymocyte apoptosis (94); and that the biochemical and morphological changes induced by ATPe and leading to apoptosis, are preceded by a rapid intracellular calcium increase (94). It was then documented that $\mathrm{P} 2 \mathrm{X} 7$ receptor is critical for apoptosis of BALB/c thymocytes induced by ATPe (18). In fact, the potent $\mathrm{P} 2 \mathrm{X} 7$ receptor agonist, benzoylbenzoyl-ATP, was able to mimic the ATPe effect. Furthermore, two P2X7 receptor antagonists (oATP and pyridoxalphosphate-6-azophenyl- $2^{\prime}, 4^{\prime}$-disulfonic acid) inhibited the effect of ATPe. However, notable evidence emanated from the use of thymocytes prepared from P2X7R $\mathrm{R}^{-1-}$ mice, where ATPe-induced apoptosis was completely abolished (18). Interestingly, ATPe could also induce activation of T cells $(19,95)$; and it appears that whether cells will undergo apoptosis or activation would depend on the level of expression of the P2X7 receptor and on concentrations of $\operatorname{ATPe}(19,95)$. High concentrations of ATPe induce apoptosis, in contrast, lower ATPe doses closer to those secreted in an autocrine or paracrine manner would induce T cell activation (19). Indeed, Junger and colleagues showed that $\mathrm{P} 2 \mathrm{X} 7$ receptors are critical for TCR-mediated $\mathrm{Ca}^{2+}$ influx and downstream signaling events accompanying $\mathrm{T}$ cell activation. The authors were able to reveal secretion of ATP $(<100 \mu \mathrm{M})$ by Jurkat cells after TCR stimulation. Subsequently, they showed that released ATPe activates $\mathrm{P} 2 \mathrm{X} 7$ receptors, in an autocrine manner, contributing to $\mathrm{Ca}^{2+}$ influx, which induces $\mathrm{T}$ cell activation via the activation of NFAT and IL-2 gene transcription (19). In 
addition to $\mathrm{P} 2 \mathrm{X} 7$ receptor, the expression and involvement of two other critical members, P2X1 and P2X4, in calcium entry and $\mathrm{T}$ cell activation was reported (20). In this study, it was shown that $\mathrm{P} 2 \mathrm{X} 1, \mathrm{P} 2 \mathrm{X} 4$ receptors and pannexin-1 hemichannels translocate to the immunological synapse of activated $\mathrm{T}$ cells. Inhibition of pannexin-1, using the gap junction inhibitor carbenoxolone, resulted in the inhibition of TCR-mediated ATP release, $\mathrm{Ca}^{2+}$ influx and $\mathrm{T}$ cell activation. Similarly, inhibition or silencing of $\mathrm{P} 2 \mathrm{X} 1$ and $\mathrm{P} 2 \mathrm{X} 4$ receptors suppresses $\mathrm{Ca}^{2+}$ entry and subsequent signaling events leading to $\mathrm{T}$ cell activation, such as NFAT activation and IL-2 gene induction (20). These reports indicate that $\mathrm{P} 2 \mathrm{X} 1, \mathrm{P} 2 \mathrm{X} 4$, and $\mathrm{P} 2 \mathrm{X} 7$ receptors play critical roles in TCR-mediated $\mathrm{Ca}^{2+}$ signal amplification upon stimulation of T lymphocytes.

\section{PERSPECTIVES AND CONCLUDING REMARKS}

Calcium ion is a critical and universal second messenger, which is involved in $\mathrm{T}$ lymphocyte function at various stages including development, survival, activation, differentiation, cytokine production, and cell death. In this review, we presented our views on the crucial role played by L-type $\mathrm{Ca}_{\mathrm{v}} 1$ channels in $\mathrm{T}$ cells. We also summarized the important discovery of the main elements controlling $\mathrm{Ca}^{2+}$ entry through CRAC channels in T cells, STIM, and ORAI. The contribution of other $\mathrm{Ca}^{2+}$ entry pathways such as the TRP family of channels and ligand-gated P2X receptors was also taken into consideration. Collectively, data reviewed in this manuscript show that $\mathrm{T}$ lymphocytes express a considerable number of $\mathrm{Ca}^{2+}$ permeable channels (see Table 1),

\section{REFERENCES}

1. Cantrell D. T cell antigen receptor signal transduction pathways. Annu Rev Immunol (1996) 14:259-74. doi:10.1146/annurev. immunol.14.1.259

2. Dolmetsch RE, Lewis RS, Goodnow CC, Healy JI. Differential activation of transcription factors induced by $\mathrm{Ca} 2+$ response amplitude and duration. Nature (1997) 386:855-8. doi:10.1038/ 386855a 0

3. Esser MT, Haverstick DM, Fuller CL, Gullo CA, Braciale VL. Ca2+ signaling modulates cytolytic $\mathrm{T}$ lymphocyte effector functions. $J$ Exp Med (1998) 187:1057-67. doi: 10.1084/jem.187.7.1057

4. Lewis RS. Calcium signaling mechanisms in $\mathrm{T}$ lymphocytes. Annu Rev Immunol (2001) 19:497. doi:10.1146/annurev.immunol.19. 1.497

5. Hogan PG, Rao A. Dissecting ICRAC, a store-operated calcium current. Trends Biochem Sci (2007) 32:235-45. doi:10.1016/j. tibs.2007.03.009

6. Lewis RS. The molecular choreography of a store-operated calcium channel. Nature (2007) 446:284-7. doi:10.1038/nature05637
7. Feske S, Skolnik EY, Prakriya M. Ion channels and transporters in lymphocyte function and immunity. Nat Rev Immunol (2012) 12:532-47. doi:10.1038/nri3233

8. Gallo EM, Cante-Barrett K, Crabtree GR. Lymphocyte calcium signaling from membrane to nucleus. Nat Immunol (2006) 7:25-32. doi: 10.1038/ni1295

9. Vig M, Kinet JP. Calcium signaling in immune cells. Nat Immunol (2009) 10:21-7. doi:10.1038/ni.f. 220

10. Feske $\mathrm{S}$. $\mathrm{Ca}(2+)$ influx in $\mathrm{T}$ cells: how many $\mathrm{ca}(2+)$ channels? Front Immunol (2013) 4:99. doi:10.3389/ fimmu.2013.00099

11. Liou J, Kim ML, Heo WD, Jones JT, Myers JW, Ferrell JE $\mathrm{Jr}$, et al. STIM is a Ca2+ sensor essential for $\mathrm{Ca} 2+$-storedepletion-triggered $\mathrm{Ca} 2+$ influx. Curr Biol (2005) 15:1235-41. doi: 10.1016/j.cub.2005.05.055

12. Zhang SL, Yu Y, Roos J, Kozak JA, Deerinck TJ, Ellisman $\mathrm{MH}$, et al. STIM1 is a $\mathrm{Ca} 2+$ sensor that activates CRAC channels and migrates from the $\mathrm{Ca} 2+$ store to the plasma membrane. Nature (2005) 437:902-5. doi:10. 1038/nature04147

which highly likely communicate together in order to regulate development and distinct functions of $\mathrm{T}$ cells. However, many questions still remain to be answered. While there is no doubt for a role of $\mathrm{Ca}_{\mathrm{v}} 1$ channel proteins in contributing to $\mathrm{Ca}^{2+}$ entry in $\mathrm{T}$ cells, it has still not been established that it is the $\mathrm{Ca}_{\mathrm{v}} 1$ pore-forming protein that conducts $\mathrm{Ca}^{2+}$ after TCR stimulation. Site-directed mutagenesis experiments could answer this important question. We also have presented evidence showing that $\mathrm{Ca}_{\mathrm{v}} 1$ channels expressed by $\mathrm{T}$ cells are not voltage-sensitive and contribute to $\mathrm{Ca}^{2+}$ entry after TCR stimulation $(27,29,31,32)$. How $\mathrm{Ca}_{\mathrm{v}} 1$ channels are gated after TCR stimulation is still not clear. Another major point is how different $\mathrm{Ca}_{\mathrm{v}} 1, \mathrm{CRAC}$, TRP, and P2XR subsets contribute, physiologically, to development of $\mathrm{T}$ cells, but especially to their differentiation into various effector $\mathrm{T}$ cell subpopulations. As shown with distinct subsets of $\mathrm{Ca}_{\mathrm{v}} 1$ family of channels, the repertoire of $\mathrm{Ca}^{2+}$ channels operating in $\mathrm{T}$ cells changes during various stages of differentiation. A more profound study of the expression level of various channels after TCR stimulation, at various differentiation stages and under physiological conditions, will be of major interest. We believe that it will be of importance, therapeutically, to target a channel that is expressed at a specific stage on a specific $\mathrm{T}$ cell subpopulation rather than robust blockage of the entire immune system, which leads to major side effects. We also need to uncover factors that are implicated in physiological regulation of these channels. Ultimately, it will be crucial to understand how all these channels interact with each other to finely regulate $\mathrm{T}$ lymphocyte functions.

13. Feske S, Gwack Y, Prakriya M, Srikanth S, Puppel SH, Tanasa B, et al. A mutation in Orail causes immune deficiency by abrogating CRAC channel function. Nature (2006) 441:179-85. doi:10.1038/ nature 04702

14. Vig M, Beck A, Billingsley JM, Lis A, Parvez S, Peinelt C, et al. CRACM1 multimers form the ionselective pore of the CRAC channel. Curr Biol (2006) 16:2073-9. doi:10.1016/j.cub.2006.08.085

15. Venkatachalam K, Ma HT, Ford DL, Gill DL. Expression of functional receptor-coupled TRPC3 channels in DT40 triple receptor InsP3 knockout cells. J Biol Chem (2001) 276:33980-5. doi:10.1074/ jbc.C100321200

16. Philipp S, Strauss B, Hirnet D, Wissenbach U, Mery L, Flockerzi $\mathrm{V}$, et al. TRPC3 mediates T-cell receptor-dependent calcium entry in human T-lymphocytes. J Biol Chem (2003) 278:26629-38. doi: 10.1074/jbc.M304044200

17. Putney JW Jr. Capacitative calcium entry: sensing the calcium stores. $J$ Cell Biol (2005) 169:381-2. doi:10. 1083/jcb.200503161

18. Le Stunff H, Auger R, Kanellopoulos J, Raymond MN. The
Pro-451 to Leu polymorphism within the C-terminal tail of P2X7 receptor impairs cell death but not phospholipase $\mathrm{D}$ activation in murine thymocytes. $J$ Biol Chem (2004) 279:16918-26. doi: 10.1074/jbc.M313064200

19. Yip L, Woehrle T, Corriden R, Hirsh $\mathrm{M}$, Chen $\mathrm{Y}$, Inoue $\mathrm{Y}$, et al. Autocrine regulation of $\mathrm{T}$ cell activation by ATP release and P2X7 receptors. FASEB J (2009) 23:1685-93. doi:10.1096/fj. 08- 126458

20. Woehrle T, Yip L, Elkhal A, Sumi Y, Chen Y, Yao Y, et al. Pannexin1 hemichannel-mediated ATP release together with $\mathrm{P} 2 \mathrm{X} 1$ and $\mathrm{P} 2 \mathrm{X} 4$ receptors regulate $\mathrm{T}$-cell activation at the immune synapse. Blood (2010) 116:3475-84. doi:10. 1182/blood-2010-04-277707

21. Catterall WA. Structure and regulation of voltage-gated $\mathrm{Ca} 2+$ channels. Annu Rev Cell Dev Biol (2000) 16:521-55. doi:10.1146/annurev. cellbio.16.1.521

22. Jiang Y, Ruta V, Chen J, Lee A, Mackinnon R. The principle of gating charge movement in a voltage-dependent $\mathrm{K}+$ channel. Nature (2003) 423:42-8. doi:10. $1038 /$ nature 01580 
23. Kotturi MF, Carlow DA, Lee JC, Ziltener HJ, Jefferies WA. Identification and functional characterization of voltage-dependent calcium channels in $\mathrm{T}$ lymphocytes. J Biol Chem (2003) 278: 46949-60. doi:10.1074/jbc. M309268200

24. Gomes B, Savignac M, Moreau M, Leclerc C, Lory P, Guery JC, et al. Lymphocyte calcium signaling involves dihydropyridine-sensitive L-type calcium channels: facts and controversies. Crit Rev Immunol (2004) 24:425-47. doi:10.1615/ CritRevImmunol.v24.i6.30

25. Stokes L, Gordon J, Grafton G. Non-voltage-gated L-type $\mathrm{Ca} 2+$ channels in human $\mathrm{T}$ cells: pharmacology and molecular characterization of the major alpha pore-forming and auxiliary beta-subunits. J Biol Chem (2004) 279:19566-73. doi:10.1074/jbc.M401481200

26. Kotturi MF, Jefferies WA. Molecular characterization of L-type calcium channel splice variants expressed in human $\mathrm{T}$ lymphocytes. Mol Immunol (2005) 42:1461-74. doi:10.1016/j. molimm.2005.01.014

27. Badou A, Jha MK, Matza D, Mehal WZ, Freichel M, Flockerzi V, et al. Critical role for the beta regulatory subunits of Cav channels in T lymphocyte function. Proc Natl Acad Sci U S A (2006) 103:15529-34. doi:10.1073/pnas.0607262103

28. Kotturi MF, Hunt SV, Jefferies WA. Roles of CRAC and Cav-like channels in $\mathrm{T}$ cells: more than one gatekeeper? Trends Pharmacol Sci (2006) 27:360-7. doi:10.1016/ j.tips.2006.05.007

29. Matza D, Badou A, Kobayashi KS, Goldsmith-Pestana K, Masuda Y, Komuro A, et al. A scaffold protein, AHNAK1, is required for calcium signaling during $\mathrm{T}$ cell activation. Immunity (2008) 28:64-74. doi:10.1016/j.immuni. 2007.11.020

30. Colucci A, Giunti R, Senesi S, Bygrave FL, Benedetti A, Gamberucci A. Effect of nifedipine on capacitive calcium entry in Jurkat T lymphocytes. Arch Biochem Biophys (2009) 481:80-5. doi:10. 1016/j.abb.2008.10.002

31. Jha MK, Badou A, Meissner M, McRory JE, Freichel M, Flockerzi V, et al. Defective survival of naive CD8+ $\mathrm{T}$ lymphocytes in the absence of the beta3 regulatory subunit of voltage-gated calcium channels. Nat Immunol (2009) 10:1275-82. doi:10.1038/ni.1793
32. Omilusik K, Priatel JJ, Chen X, Wang YT, Xu H, Choi KB, et al. The $\mathrm{Ca}(\mathrm{v}) 1.4$ calcium channel is a critical regulator of $\mathrm{T}$ cell receptor signaling and naive $\mathrm{T}$ cell homeostasis. Immunity (2011) 35:34960. doi:10.1016/j.immuni.2011.07. 011

33. Matza D, Badou A, Jha MK, Willinger T, Antov A, Sanjabi $S$, et al. Requirement for AHNAK1-mediated calcium signaling during $\mathrm{T}$ lymphocyte cytolysis. Proc Natl Acad Sci U S A (2009) 106:9785-90. doi:10.1073/pnas.0902844106

34. Badou A, Savignac M, Moreau M, Leclerc C, Pasquier R, Druet P, et al. $\mathrm{HgCl}_{2}$-induced interleukin-4 gene expression in $\mathrm{T}$ cells involves a protein kinase C-dependent calcium influx through L-type calcium channels. J Biol Chem (1997) 272:32411-8. doi:10.1074/jbc. 272. 51.32411

35. Matza D, Flavell RA. Roles of $\mathrm{Ca}(\mathrm{v})$ channels and AHNAK1 in T cells: the beauty and the beast. Immunol Rev (2009) 231:257-64. doi:10. 1111/j.1600-065X.2009.00805.x

36. Cabral MD, Paulet PE, Robert V, Gomes B, Renoud ML, Savignac M, et al. Knocking down Cav1 calcium channels implicated in Th2 cell activation prevents experimental asthma. Am J Respir Crit Care Med (2010) 181:1310-7. doi:10.1164/ rccm.200907-1166OC

37. Sadighi Akha AA, Willmott NJ, Brickley K, Dolphin AC, Galione A, Hunt SV. Anti-Ig-induced calcium influx in rat B lymphocytes mediated by cGMP through a dihydropyridinesensitive channel. J Biol Chem (1996) 271:7297-300. doi:10.1074/jbc.271.13.7297

38. Grafton G, Stokes L, Toellner KM, Gordon J. A non-voltage-gated calcium channel with L-type characteristics activated by B cell receptor ligation. Biochem Pharmacol (2003) 66:2001-9. doi:10.1016/j. bcp.2003.07.005

39. Vukcevic M, Spagnoli GC, Iezzi G, Zorzato F, Treves S. Ryanodine receptor activation by $\mathrm{Ca}$ $\mathrm{v} 1.2$ is involved in dendritic cell major histocompatibility complex class II surface expression. J Biol Chem (2008) 283:34913-22. doi: 10.1074/jbc.M804472200

40. Fill M, Copello JA. Ryanodine receptor calcium release channels. Physiol Rev (2002) 82: 893-922.

41. Hakamata Y, Nishimura S, Nakai J, Nakashima Y, Kita T, Imoto
K. Involvement of the brain type of ryanodine receptor in T-cell proliferation. FEBS Lett (1994) 352:206-10. doi:10.1016/ 0014-5793(94)00955-4

42. Hosoi E, Nishizaki C, Gallagher KL, Wyre HW, Matsuo Y, Sei Y. Expression of the ryanodine receptor isoforms in immune cells. J Immunol (2001) 167:4887-94.

43. Hohenegger M, Berg I, Weigl L, Mayr GW, Potter BV, Guse AH. Pharmacological activation of the ryanodine receptor in Jurkat T-lymphocytes. $\mathrm{Br} J$ Pharmacol (1999) 128:1235-40. doi:10.1038/ sj.bjp.0702935

44. Conrad DM, Hanniman EA, Watson CL, Mader JS, Hoskin DW. Ryanodine receptor signaling is required for anti-CD3-induced $\mathrm{T}$ cell proliferation, interleukin-2 synthesis, and interleukin-2 receptor signaling. J Cell Biochem (2004) 92:387-99. doi:10.1002/jcb.20064

45. Schwarzmann N, Kunerth S, Weber K, Mayr GW, Guse AH. Knockdown of the type 3 ryanodine receptor impairs sustained $\mathrm{Ca} 2+$ signaling via the $\mathrm{T}$ cell receptor/CD3 complex. J Biol Chem (2002) 277:50636-42. doi: 10.1074/jbc.M209061200

46. Dadsetan S, Zakharova L, Molinski TF, Fomina AF. Store-operated $\mathrm{Ca} 2+$ influx causes $\mathrm{Ca} 2+$ release from the intracellular $\mathrm{Ca} 2+$ channels that is required for $\mathrm{T}$ cell activation. $J$ Biol Chem (2008) 283:12512-9. doi:10.1074/ jbc.M709330200

47. Dickie MM. Lethargic (lh). Mouse News Lett (1964) 30:31.

48. Sidman RL, Green MC, Appel SH. Catalog of the Neurological Mutants of the Mouse. Cambridge, MA: Harvard University Press (1965). $34 \mathrm{p}$.

49. Burgess DL, Jones JM, Meisler $\mathrm{MH}$, Noebels JL. Mutation of the $\mathrm{Ca} 2+$ channel beta subunit gene Cchb4 is associated with ataxia and seizures in the lethargic (lh) mouse. Cell (1997) 88: 385-92. doi:10.1016/S00928674(00)81877-2

50. Morrison DG, Moyer MP, Dung HC, Rogers W, Moyer RC. Tumor growth rate varies with age in lethargic mutant $\mathrm{BALB} / \mathrm{cGnDu}$ mice. Dev Comp Immunol (1984) 8:435-42. doi:10.1016/0145 305X(84)90050-8

51. Dolphin AC. Beta subunits of voltage-gated calcium channels. $J$ Bioenerg Biomembr (2003) 35:599-620. doi:10.1023/B:JOBB. $0000008026.37790 .5 \mathrm{a}$
52. Bichet D, Lecomte C, Sabatier JM, Felix R, De Waard M. Reversibility of the $\mathrm{Ca}(2+)$ channel alpha(1)-beta subunit interaction. Biochem Biophys Res Commun (2000) 277:729-35. doi:10. 1006/bbrc. 2000.3750

53. McRory JE, Hamid J, Doering CJ, Garcia E, Parker R, Hamming $\mathrm{K}$, et al. The CACNA1F gene encodes an L-type calcium channel with unique biophysical properties and tissue distribution. J Neurosci (2004) 24:1707-18. doi:10.1523/JNEUROSCI.484603.2004

54. Doering CJ, Rehak R, Bonfield S, Peloquin JB, Stell WK, Mema SC, et al. Modified $\mathrm{Ca}(\mathrm{v}) 1.4$ expression in the Cacnalf(nob2) mouse due to alternative splicing of an ETn inserted in exon 2. PLoS ONE (2008) 3:e2538. doi:10.1371/ journal.pone.0002538

55. Berridge MJ, Bootman MD, Roderick HL. Calcium signalling: dynamics, homeostasis and remodelling. Nat Rev Mol Cell Biol (2003) 4:517-29. doi:10.1038/nrm1155

56. Pani B, Singh BB. Lipid rafts/caveolae as microdomains of calcium signaling. Cell Calcium (2009) 45:625-33. doi:10.1016/j.ceca.2009.02.009

57. Kim KD, Srikanth S, Yee MK, Mock DC, Lawson GW, Gwack Y. ORAI1 deficiency impairs activated $\mathrm{T}$ cell death and enhances $\mathrm{T}$ cell survival. I Immunol (2011) 187:3620-30. doi:10.4049/jimmunol.1100847

58. Park CY, Shcheglovitov A, Dolmetsch R. The CRAC channel activator STIM1 binds and inhibits Ltype voltage-gated calcium channels. Science (2010) 330:101-5. doi:10.1126/science.1191027

59. Wang Y, Deng X, Mancarella S, Hendron E, Eguchi S, Soboloff J, et al. The calcium store sensor, STIM1, reciprocally controls Orai and CaV1.2 channels. Science (2010) 330:105-9. doi:10. 1126/science. 1191086

60. Savignac M, Gomes B, Gallard A, Narbonnet S, Moreau $M$, Leclerc C, et al. Dihydropyridine receptors are selective markers of Th2 cells and can be targeted to prevent Th2-dependent immunopathological disorders. J Immunol (2004) 172:5206-12.

61. Gomes B, Cabral MD, Gallard A, Savignac M, Paulet P, Druet P, et al. Calcium channel blocker prevents $\mathrm{T}$ helper type 2 cellmediated airway inflammation. Am J Respir Crit Care Med 
(2007) 175:1117-24. doi:10.1164/ rccm.200607-1026OC

62. Tsien RW, Fox AP, Hess P, Mccleskey EW, Nilius B, Nowycky $\mathrm{MC}$, et al. Multiple types of calcium channel in excitable cells. Soc Gen Physiol Ser (1987) 41:167-87.

63. Lipscombe D, Helton TD, Xu W. L-type calcium channels: the low down. J Neurophysiol (2004) 92:2633-41. doi:10.1152/jn.00486. 2004

64. Koschak A, Reimer D, Huber I, Grabner M, Glossmann H, Engel J, et al. Alpha 1D (Cavl.3) subunits can form 1-type Ca2+ channels activating at negative voltages. $J$ Biol Chem (2001) 276:22100-6. doi:10.1074/jbc.M101469200

65. Rosenberg P, Hawkins A, Stiber J, Shelton JM, Hutcheson K, Bassel-Duby R, et al. TRPC3 channels confer cellular memory of recent neuromuscular activity. Proc Natl Acad Sci U S A (2004) 101:9387-92. doi:10.1073/ pnas.0308179101

66. Gelfand EW, Cheung RK, Grinstein S. Mitogen-induced changes in $\mathrm{Ca} 2+$ permeability are not mediated by voltage-gated $\mathrm{K}+$ channels. J Biol Chem (1986) 261:11520-3.

67. Freedman BD, Price MA, Deutsch CJ. Evidence for voltage modulation of IL-2 production in mitogen-stimulated human peripheral blood lymphocytes. $J$ Immunol (1992) 149:3784-94.

68. Hogan PG, Lewis RS, Rao A. Molecular basis of calcium signaling in lymphocytes: STIM and ORAI. Annu Rev Immunol (2010) 28:491-533. doi:10.1146/annurev. immunol.021908.132550

69. Putney JW Jr. A model for receptor-regulated calcium entry. Cell Calcium (1986) 7:1-12. doi: 10.1016/0143-4160(86)90026-6

70. Parekh AB, Putney JW Jr. Storeoperated calcium channels. Physiol Rev (2005) 85:757-810. doi:10. 1152/physrev.00057.2003

71. Zweifach A, Lewis RS. Mitogenregulated $\mathrm{Ca} 2+$ current of $\mathrm{T}$ lymphocytes is activated by depletion of intracellular $\mathrm{Ca} 2+$ stores. Proc Natl Acad Sci U S A (1993) 90:6295-9. doi:10.1073/ pnas.90.13.6295

72. Roos J, Digregorio PJ, Yeromin $\mathrm{AV}$, Ohlsen K, Lioudyno M, Zhang $S$, et al. STIM1, an essential and conserved component of storeoperated $\mathrm{Ca} 2+$ channel function. J Cell Biol (2005) 169:435-45. doi: $10.1083 /$ icb. 200502019
73. Vig M, Peinelt C, Beck A, Koomoa DL, Rabah D, Koblan-Huberson $\mathrm{M}$, et al. CRACM1 is a plasma membrane protein essential for store-operated Ca2+ entry. Science (2006) 312:1220-3. doi:10.1126/ science. 1127883

74. Zhang SL, Yeromin AV, Zhang $\mathrm{XH}$, Yu Y, Safrina O, Penna A, et al. Genome-wide RNAi screen of $\mathrm{Ca}(2+)$ influx identifies genes that regulate $\mathrm{Ca}(2+)$ release-activated $\mathrm{Ca}(2+)$ channel activity. Proc Natl Acad Sci U S A (2006) 103: 9357-62. doi:10.1073/pnas. 0603161103

75. Prakriya M, Feske S, Gwack Y, Srikanth S, Rao A, Hogan PG. Orail is an essential pore subunit of the CRAC channel. Nature (2006) 443:230-3. doi:10.1038/ nature 05122

76. Yeromin AV, Zhang SL, Jiang W, Yu Y, Safrina O, Cahalan MD. Molecular identification of the CRAC channel by altered ion selectivity in a mutant of Orai. Nature (2006) 443:226-9. doi:10. 1038/nature05108

77. Vig M, Dehaven WI, Bird GS, Billingsley JM, Wang $\mathrm{H}$, Rao $\mathrm{PE}$, et al. Defective mast cell effector functions in mice lacking the CRACM1 pore subunit of store-operated calcium releaseactivated calcium channels. Nat Immunol (2008) 9:89-96. doi:10. 1038/nrg2314

78. Gwack Y, Srikanth S, Oh-Hora M, Hogan PG, Lamperti ED, Yamashita M, et al. Hair loss and defective T- and B-cell function in mice lacking ORAI1. Mol Cell Biol (2008) 28:5209-22. doi:10.1128/ MCB.00360-08

79. Venkatachalam K, Montell C. TRP channels. Annu Rev Biochem (2007) 76:387-417. doi:10.1146/annurev.biochem.75. 103004.142819

80. Ramsey IS, Delling M, Clapham DE. An introduction to TRP channels. Annu Rev Physiol (2006) 68:619-47. doi:10.1146/annurev. physiol.68.040204.100431

81. Inada $H$, Iida $T$, Tominaga $M$. Different expression patterns of TRP genes in murine $B$ and $T$ lymphocytes. Biochem Biophys Res Commun (2006) 350:762-7. doi: 10.1016/j.bbrc.2006.09.111

82. Wenning AS, Neblung K, Strauss B, Wolfs MJ, Sappok A, Hoth $\mathrm{M}$, et al. TRP expression pattern and the functional importance of TRPC3 in primary human T-cells. Biochim Biophys Acto
(2011) 1813:412-23. doi:10.1016/ j.bbamcr.2010.12.022

83. Fanger CM, Hoth M, Crabtree GR, Lewis RS. Characterization of T cell mutants with defects in capacitative calcium entry: genetic evidence for the physiological roles of CRAC channels. J Cell Biol (1995) 131:655-67. doi:10.1083/ jcb.131.3.655

84. Wang J, Lu ZH, Gabius HJ, Rohowsky-Kochan C, Ledeen RW, Wu G. Cross-linking of GM1 ganglioside by galectin1 mediates regulatory $\mathrm{T}$ cell activity involving TRPC5 channel activation: possible role in suppressing experimental autoimmune encephalomyelitis. J Immunol (2009) 182:4036-45. doi:10.4049/jimmunol.0802981

85. Perraud AL, Fleig A, Dunn CA, Bagley LA, Launay P, Schmitz $\mathrm{C}$, et al. ADP-ribose gating of the calcium-permeable LTRPC2 channel revealed by Nudix motif homology. Nature (2001) 411:595-9. doi:10.1038/35079100

86. Sano Y, Inamura K, Miyake A, Mochizuki S, Yokoi H, Matsushime $\mathrm{H}$, et al. Immunocyte $\mathrm{Ca} 2+$ influx system mediated by LTRPC2. Science (2001) 293:1327-30. doi:10. 1126/science. 1062473

87. Gasser A, Glassmeier G, Fliegert R, Langhorst MF, Meinke S, Hein $\mathrm{D}$, et al. Activation of $\mathrm{T}$ cell calcium influx by the second messenger ADP-ribose. J Biol Chem (2006) 281:2489-96. doi:10.1074/ jbc.M506525200

88. Magnone M, Bauer I, Poggi A, Mannino E, Sturla L, Brini $\mathrm{M}$, et al. NAD+ levels control $\mathrm{Ca} 2+$ store replenishment and mitogen-induced increase of cytosolic Ca2+ by Cyclic ADPribose-dependent TRPM2 channel gating in human T lymphocytes. J Biol Chem (2012) 287: 21067-81. doi:10.1074/jbc.M111. 324269

89. Melzer N, Hicking G, Gobel K, Wiendl H. TRPM2 cation channels modulate $\mathrm{T}$ cell effector functions and contribute to autoimmune CNS inflammation. PLoS ONE (2012) 7:e47617. doi:10 1371/journal.pone.0047617

90. Schmitz C, Perraud AL, Johnson $\mathrm{CO}$, Inabe $\mathrm{K}$, Smith MK, Penner $\mathrm{R}$, et al. Regulation of vertebrate cellular $\mathrm{Mg} 2+$ homeostasis by TRPM7. Cell (2003) 114:191200. doi:10.1016/S0092-8674(03) 00556-7
91. Jin J, Desai BN, Navarro B, Donovan A, Andrews NC, Clapham DE. Deletion of Trpm7 disrupts embryonic development and thymopoiesis without altering $\mathrm{Mg} 2+$ homeostasis. Science (2008) 322:756-60. doi:10.1126/science.1163493

92. Desai BN, Krapivinsky G, Navarro B, Krapivinsky L, Carter BC, Febvay S, et al. Cleavage of TRPM7 releases the kinase domain from the ion channel and regulates its participation in Fas-induced apoptosis. Dev Cell (2012) 22:1149-62. doi:10.1016/j.devcel. 2012.04.006

93. Baricordi OR, Ferrari D, Melchiorri L, Chiozzi P, Hanau S, Chiari E, et al. An ATP-activated channel is involved in mitogenic stimulation of human T lymphocytes. Blood (1996) 87:682-90.

94. Zheng LM, Zychlinsky A, Liu CC, Ojcius DM, Young JD. Extracellular ATP as a trigger for apoptosis or programmed cell death. $J$ Cell Biol (1991) 112:279-88. doi: 10.1083/jcb.112.2.279

95. Aswad F, Dennert G. P2X7 receptor expression levels determine lethal effects of a purine based danger signal in T lymphocytes. Cell Immunol (2006) 243:58-65. doi: 10.1016/j.cellimm.2006.12.003

Conflict of Interest Statement: The authors declare that the research was conducted in the absence of any commercial or financial relationships that could be construed as a potential conflict of interest.

Received: 31 May 2013; accepted: 05 August 2013; published online: 30 August 2013.

Citation: Badou A, Jha MK, Matza $D$ and Flavell RA (2013) Emerging roles of L-type voltage-gated and other calcium channels in $T$ lymphocytes. Front. Immunol. 4:243. doi: 10.3389/fimmu. 2013.00243

This article was submitted to TCell Biology, a section of the journal Frontiers in Immunology.

Copyright () 2013 Badou, Jha, Matza and Flavell. This is an open-access article distributed under the terms of the Creative Commons Attribution License (CC $B Y)$. The use, distribution or reproduction in other forums is permitted, provided the original author(s) or licensor are credited and that the original publication in this journal is cited, in accordance with accepted academic practice. No use, distribution or reproduction is permitted which does not comply with these terms. 